\title{
Testing the Effect of Employee Engagement, Transformational Leadership and Organisational Communication on Organisational Commitment
}

\author{
Ngqabutho Moyo \\ School of Business, Jiangsu Normal University, 101 Shanghai Road, Tongshan New District, Xuzhou, Jiangsu Province, China
}

\begin{abstract}
Objective - Organisational commitment has emerged as a major source of competitive advantage for many organizations. Its dominance and significance in the field of academia and business is highly attributed to its incredible benefits such as improved employee performance, productivity, loyalty, responsibility, job satisfaction, motivation and a harmonious industrial relations system. Based on Meyer and Allen's (1991) Three-Component Model of Organisational Commitment, the current study acknowledges organisational commitment as a psychological state that is made up of affective, normative and continuance commitment, and that it is attributed to a diverse range of factors. As such, the primary objective of this research is to trace the antecedents of organisational commitment and test the effects of some of the key factors affecting organisational commitment, namely: employee engagement, transformational leadership and organisational communication.

Findings - The findings of this research indicate that employee engagement, transformational leadership and organisational communication have a significant positive effect on organisational commitment.

Novelty - Organizations should identify key drivers of organisational commitment and ensure their continuous assessment so as to encourage effective organisational commitment among employees.
\end{abstract}

Type of Paper: Empirical.

Keywords: Employee Engagement; Organisational Commitment; Organisational Communication; Transformational Leadership.

Reference to this paper should be made as follows: Moyo, N. (2019). Testing the Effect of Employee Engagement, Transformational Leaderhip and Organisational Communication on Organisational Commitment, J. Mgt. Mkt. Review, 4(4) 270 - 278 https://doi.org/10.35609/jmmr.2019.4.4(6)

JEL Classification: M10, M12, M19.

\section{Introduction}

Enhancing organisational commitment among employees has attracted the attention of many researchers and organisational participants due to its significance in stimulating effective organisational performance.

\footnotetext{
* Paper Info: Revised: September 14, 2019

Accepted: December 30, 2019

* Corresponding author: Ngqabutho Moyo

E-mail: ngqabuthoemoyoe1@gmail.com

Affiliation: School of Business, Jiangsu Normal University, Xuzhou, China
} 
Ngqabutho Moyo

Ghorbanhosseini (2012) defines organisational commitment as the level of attachment and loyalty that employees have towards their organization. Based on the findings of previous studies, committed employees are the most valuable assets of an organisation. According to Hanaysha (2016), organisational commitment enhances employee productivity and loyalty and encourages employees to be harmonious and to possess higher levels of job satisfaction and responsibility in their workplace. Therefore, it is of paramount importance for companies to identify the key drivers of organisational commitment so as to ensure its effectiveness (Lo, Ramayah \& Min, 2010). Previous studies have suggested that organisational commitment is highly influenced by factors such as work environment, employee engagement, organisational learning (Hanaysha, 2016), leadership (Lo et. al., 2010) and communication (Carriere \& Bourque, 2009). According to Sze et. al. (2016), the commitment of Generation X employees is highly attributed to factors such as task orientation, organisational justice, training and development, compensation and incentives and knowledge sharing.

Although many researchers have explored the concept of organisational commitment, little attention has been directed towards examining the key factors affecting organisational commitment within the Energy Industry of Zimbabwe. Hence, to the existing literature and in an attempt to cover the identified research gap, this study is contributing in the following ways: Firstly, the study introduces a novel approach which identifies and tests the three key factors affecting organisational commitment within the Energy Industry of Zimbabwe using a Structural Equation Model (SEM). The identified factors include employee engagement, transformational leadership and organisational communication. No previous researchers have explored a similar relationship that exists among a combination of the above mentioned constructs in the context of the Energy Industry of Zimbabwe using a Structural Equation Model.

In conjunction with the above analysis, the findings of this research prove that a combination of employee engagement, transformational leadership and organisational communication has a positive effect on organisational commitment. By carefully determining, testing and attaining positive results on this relationship, organisations are encouraged to ensure a continuous assessment of these factors so as to boost employees' organisational communication.

Secondly, this study gives new insight on the significant role played by managers in reinforcing organisational commitment. Through their expertise, managers are in a better position to ensure the execution of the best suitable leadership styles that arouse employees' job satisfaction, engagement and commitment. Moreover, managers are also responsible for creating effective channels of organisational communication that are open and non-discriminatory in nature so as to accommodate all organisational participants. Lastly, this study also reveals that employee commitment is very essential since it is associated with benefits such as employee motivation, a harmonious industrial relations system, improved employee performance, loyalty, productivity, job satisfaction and responsibility.

The rest of this paper is organized as follows: Section 2 is the literature review, which contains the theory and full descriptions of the developed constructs of this study. Section 3 contains the research methodology, which provides a full description of the features such as the targeted sample size, research approach, the development of the measurement items and scales, the reliability and validity testing and the development of the Structural Equation Model. Section 3.1 contains the results of the descriptive statistics, reliability, validity and hypothesis testing. A discussion of the results is included in section 4 and section 5 concludes the paper.

\section{Literature Review}

\subsection{Meyer and Allen's (1991) Three-Component Model of Organisational Commitment}

According to Meyer and Allen's (1991) Three-Component Model of Organisational Commitment, commitment is a psychological state that consists of normative commitment, continuance commitment and affective commitment (Meyer \& Allen, 1991; Jaros, 1997). Affective commitment refers to a psychological desire that enhances an individual's emotional identification, involvement and attachment to the organisation 
Ngqabutho Moyo

(Meyer \& Allen, 1991). According to Meyer and Allen (1991), continuance commitment is a psychological need that encourages an individual to commit to their organisation, whereas normative commitment arises when an individual perceives that they have an obligation towards their organisation. The three highlighted components of organisational commitment in Meyer and Allen's (1991) Three-Component Model of Organisational Commitment have different implications on organisations (Janoniene \& Endriulaitiene, 2014). For instance, many researchers tend to associate affective commitment with positive effects on organisational performance (Janoniene \& Endriulaitiene, 2014).

In this research, attention was primarily directed towards affective commitment due to its focus on the emotional attachment, identification and involvement that employees have towards their organization (Dey, Kumar \& Kumar, 2014). Employees who are highly committed towards their organization tend to reflect higher levels of organisational citizenship behaviour and support, increased level of motivation and reduced turnover (Kwon \& Banks, 2004). Carriere and Bourque (2009) define organisational commitment as a helpful psychological force that binds employees to commit towards an action that is significant to the organization. It is therefore recommended that organizations should ensure a continuous assessment of organisational commitment among employees so as to reinforce its existence and enjoy its benefits.

Meyer and Allen's (1991) Three-Component Model of Organisational Commitment indicates that organisational commitment is attributed to a diverse range of factors (Meyer \& Allen, 1991). Among other factors impacting organisational commitment, this research identified employee engagement, transformational leadership and organisational communication as the key factors, and then tested their effects on organisational commitment.

\subsubsection{Employee Engagement and Organisational Commitment}

Employee engagement has emerged as an issue of concern among leaders of organisations across the globe due to its recognition as a significant component that determines the innovativeness, competitiveness and effectiveness of organisations (Bedarkar \& Pandita, 2014). This implies that the significance of employee engagement is a source of a competitive edge for organisations which cannot be undermined. According to Rasli et. al. (2012), engagement is a fulfilling, positive, work-related state of mind that comprises dedication, vigour and absorption. As for Bhappu and Schultze (2018), engaged employees are individuals who are psychologically present, focused and who fully express themselves during the performance of their tasks. Glavas (2016) defines employee engagement as a state in which employees are able to apply more of themselves; emotionally, physically and cognitively in their work performance. When this ocurrs, organisational citizenship behaviour accelerates and team performance increases, organisational outputs improve, employee retention increases and employee absenteeism reduces (Glavas, 2016). Previous studies have suggested that employee engagement has a positive effect on organisational commitment (Hanaysha, 2016; Shoko \& Zinyemba, 2014). Based on the above discussion, this following hypothesis is proposed:

H1: Employee engagement has a positive effect on organisational commitment.

\subsubsection{Transformational Leadership and Organisational Commitment}

Different leadership styles have diverse effects on employee organisational commitment. Employee organisational commitment is likely to increase if employees themselves feel more comfortable with the leadership styles of their leaders. Transformational leadership is more innovative, productive, effective and satisfying to employees since it allows followers and their leaders to have a shared vision and values, mutual respect and trust (Lo et. al., 2010). Transformational leaders are leaders who encourage their followers to think creatively and critically (Bass \& Avolio, 1993), understand the needs of their followers and transform the basic beliefs, values and attitudes of their followers as a way of promoting organizational performance (Gozukara \& Simsek, 2015). Previous research by Lo et. al. (2010) indicates that transformational leadership 
Ngqabutho Moyo

has a stronger and significant effect on organisational commitment. Therefore, based on the above discussion, the following hypothesis is proposed:

H2: Transformational leadership has a positive effect on organisational commitment.

\subsubsection{Organisational Communication and Organisational Commitment}

Communication can be defined as a process of sharing thoughts, emotions and information between two or more parties (Guney et. al., 2012). Organisational communication can be contextualised as communication that occurs within an organization. Previous studies have indicated that organisational communication has a remarkable effect on work engagement (Guney et. al., 2012). Enhancing organisational commitment through organisational communication is however dependant on the type of communication that is being used. Echoing this analysis, democratic communication, which allows information to be exchanged in an objective way among parties involved (Guney et. al., 2012) is likely to encourage organisational commitment among employees due to its openness and inclusiveness. According to Carriere and Bourque (2009), satisfaction that emanates from organisational communication is a key variable that influences commitment among employees. As such, the following hypothesis is proposed:

H3: Organisational communication has a positive effect on organisational commitment.

\section{Research Methodology}

The current study adopts a quantitative approach and relies on primary data. A quantitative approach was chosen based of the fact that it is highly regarded as the most acceptable approach in understanding the direct and indirect relationships that exists among multiple factors (Hanaysha, 2016). The research adopts a survey approach that contains self-administered questionnaires which were carefully distributed among the targeted participants.

This research randomly selected a sample of 320 participants employed within the Energy Industry of Zimbabwe. The Energy Industry of Zimbabwe is regulated as a monopoly under the Ministry of Energy and Power Development of Zimbabwe through the Zimbabwe Electricity Supply Authority (ZESA Holdings). As one of the leading monopolies in Zimbabwe, ZESA is operating as a Holding Company, in charge of its subsidiaries, namely; Zimbabwe Electricity Transmission and Distribution Company (ZETDC), Zimbabwe Power Company (ZPC), ZESA Enterprises and PowerTel. By targeting these participants, the current study has addressed the critical questions regarding the contribution of employee engagement, transformational leadership and organisational communication on organisational commitment within the Energy Industry of Zimbabwe.

In this study, independent variables include employee engagement, transformational leadership and organisational communication. Organisational commitment is the dependent variable. Measurement items of these variables were obtained and developed from a number of previous studies. For instance, measurement items of employee engagement were adapted from Schaufeli and Bakker (2003) in Hanaysha (2016), while measurement items of organisational commitment were adapted from Mowday, Steers and Porter (1979) in Hanaysha (2016). Measurement items of transformational leadership were adapted from Conger-Kanungo Charismatic The leadership scale used in this study is that which was originally developed by Conger, Kanungo, Menon and Marthur (1997). This scale was chosen based on the fact that it addresses the key aspects of transformational leadership which are of paramount importance in the enhancement of organizational commitment. On the basis of face validity, the current study selected and developed five most influential items from the Conger-Kanungo Charismatic Leadership scale. The selected items were deemed highly suitable for the current study. Measurement items of organisational communication were developed 
from Hayase (2009). All developed items were measured on a five point Likert scale that ranges from: 1 "strongly disagree" to 5 "strongly agree".

A Statistical Package for Social Sciences (SPSS version 20) was used for the analysis of descriptive statistical data. The analysis of descriptive statistical data included the analysis of data related to gender, age, employment history and education. In addition, a reliability analysis for the measurement items was also conducted on SPSS version 20 through the utilisation of Cronbach's Alpha. AMOS version 20 was utilized for Structural Equation Modeling (SEM), which included all the measurement items of the variables of this study. The Structural Equation Model was then used to conduct a Confirmatory Factor Analysis (CFA), which then produced the results of validity testing for the developed measurement items. In addition, the Structural Model was also utilised for hypothesis testing, to determine the relationship of the variables.

\subsection{Results}

\subsubsection{Descriptive Statistics}

A total of 279 respondents completed the survey. The results of descriptive statistics indicated that 230 (82.4\%) respondents were males, while the remaining 49 (17.6\%) were females. In terms of age, 79 (28.3\%) respondents fell in the age category of 21 to 30 years, while 149 (53.4\%) were in between 31 and 40 years. In addition, $48(17.2 \%)$ respondents fell in the age category of 41 to 50 years, and only $3(1.1 \%)$ respondents were above the age of 50. Out of a total of 279 (100\%) respondents, $195(69.9 \%)$ had completed Ordinary Level, while 54 (19.4\%) had only reached the Advanced Level. 14 (5.0\%) respondents had achieved a Certificate level of education at a college, while $9(3.2 \%)$ respondents had reached a Diploma level. Only 7 (2.5\%) respondents had acquired a bachelor's degree. In terms of length of service, only 87 (31.2\%) respondents had lower than 6 years of service, while $192(68.8 \%)$ had more than 5 years of service.

3.1.2 Reliability Analysis on Cronbach's Alpha

To determine the consistency and reliability of the developed measurement items, a reliability analysis was performed on Cronbach's alpha. The results of the reliability analysis on Cronbach's alpha indicated that all values were acceptable, as they ranged from 0.805 to 0.885 . Values which are close to 1 are a reflection of a good internal consistency as opposed to values close to 0.00 which represent a poor internal consistency (Cronk, 2018). Nunnally (1978) indicates that a recommendable alpha should be above 0.70 for an acceptable internal consistency.

Table 1. Results of reliability analysis on Cronbach's Alpha

\begin{tabular}{|c|c|c|}
\hline Constructs & Number of items & Cronbach's alpha \\
\hline Organisational Commitment & 5 & 0.885 \\
\hline Employee Engagement & 5 & 0.845 \\
\hline Organisational Communication & 5 & 0.805 \\
\hline Transformational Leadership & 5 & 0.853 \\
\hline
\end{tabular}

As shown in Table 1, organisational commitment accounts for 0.885 , while employee engagement recorded 0.845 . Organisational communication recorded 0.805 , while transformational leadership accounts for 0.853 . There were 5 items for each construct.

\subsubsection{Confirmatory Factor Analysis and Structural Equation Modelling}

After conducting a reliability analysis on Cronbach's alpha, a confirmatory factor analysis (CFA) was then conducted on AMOS version 20. This was made possible through the construction of a measurement model that contained all measurement items. Conducting a confirmatory factor analysis is of paramount importance 
because it ensures the validity of constructs. All factor loadings were reported between 0.79 and 1.10 . The structural model was then constructed. At this stage, a good fit for all items was ensured. As shown in Fig 1 below, the structural model achieved a good fit, giving the value of Chi-square that is equal to 458.069. Other recorded fit values include: degree of freedom $=164, \mathrm{GFI}=0.857, \mathrm{AGFI}=0.817, \mathrm{TLI}=0.884, \mathrm{CFI}=0.899$, RMSEA $=0.080$.

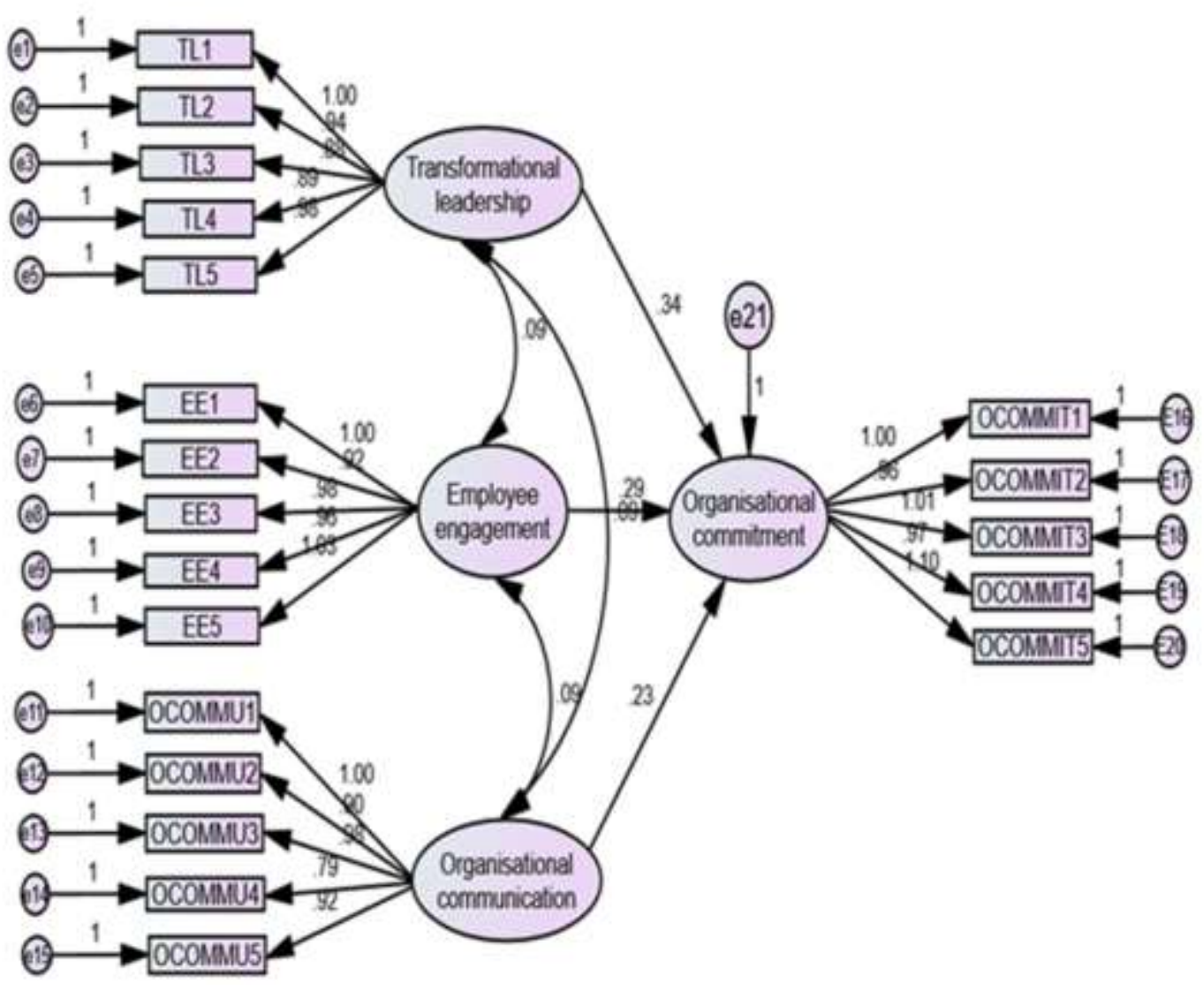

Fit values: Chi-square $=458.069($ degree of freedom $=164, \mathrm{GFI}=0.857, \mathrm{AGFI}=0.817, \mathrm{TLI}=0.884, \mathrm{CFI}$ $=0.899$, RMSEA $=0.080)$

Table 2. Results of hypotheses testing

Hypothesized Effect

$\begin{array}{lllll}\text { Est. } & \text { S.E. } & \text { C.R. } & \text { P } & \text { Decision } \\ .288 & .085 & 3.396 & * * * & \text { Supported }\end{array}$

H2: Transformational_leadership $\rightarrow$ Organisational_commitment $.341 \quad .080 \quad 4.259 * * *$ Supported

H3: Organisational_communication $\rightarrow$ Organisational_commitment $\quad .225 \quad .086 \quad 2.626 \quad .009$ Supported

As shown in Table 2, the results of hypothesis testing indicate that employee engagement has a significant positive effect on organisational commitment (standardized estimates $=0.288, \mathrm{t}-$ value $=3.396, \mathrm{p}<0.05$ ). Therefore, $\mathrm{H} 1$ is supported. The results also show that transformational leadership has a significant positive effect on organisational commitment (standardized estimates $=0.341, \mathrm{t}-$ value $=4.259, \mathrm{p}<0.05$ ). Hence H2 
Ngqabutho Moyo

was also supported. The findings also reveal that organisational communication has a significant positive effect on organisational commitment (standardized estimates $=0.225, \mathrm{t}-$ value $=2.626, \mathrm{p}<0.05$ ). As such, $\mathrm{H} 3$ is also supported.

\section{Discussion}

The findings of this research indicate that employee engagement has a significant positive effect on organisational commitment. On a similar note, research by Hanaysha (2016) and Shoko and Zinyemba (2014) reveal that employee engagement is a significant driver of organisational commitment. As such, this research implies that organisational commitment is highly dependent on employee engagement. An increase in the level of employee engagement is likely to lead to an increase in the level of employees' commitment. As such, the importance of employee engagement cannot be underestimated. According to Kaliannan and Adjovu (2015), employee engagement is an 'engine' in talent management, whose strategic initiatives support organisational reputation and branding.

This research also demonstrates that transformational leadership has a significant positive effect on organisational commitment. In conjunction with this result, research by Lo et. al. (2010) shows that organisational commitment is positively affected by transformational leadership. Through their charismatic leadership trait, transformational leaders are able to charm their followers, and as such, they are able to stimulate commitment and loyalty among them. This observation implies that transformational leaders are in a better position to win the trust, loyalty, support and affective commitment of their followers since they possess good leadership qualities.

This study also shows that organisational commitment is positively influenced by organisational communication. In support of this result, Chen, Silverthorne and Hung (2006) discovered that in organizations where communication is open and continuous, the level of organisational commitment among employees is high. Hence, organizations should come up with communication channels that are open and inclusive in nature in order to encourage effective organisational commitment.

\section{Conclusion}

Meyer and Allen's (1991) Three-Component Model of Organisational Commitment indicates that organisational commitment is attributed to a diverse range of factors. As such, one of the primary goals of this research was to identify some of the critical factors affecting organisational commitment. Factors which were identified include; organisational learning, knowledge sharing, training and development, leadership, communication, organisational justice, work environment, compensation and incentives and employee engagement. However, to contribute new knowledge in the existing literature, this research introduced a novelty approach that focused only on determining and testing the effects of a combination of the three significant factors affecting organisational commitment within the Energy Industry of Zimbabwe. Independent variables or factors which were identified and tested against organisational commitment as a dependent variable include; employee engagement, transformational leadership and organisational communication.

According to the findings of this research, employee engagement plays a pivotal role in enhancing organisational commitment. Engaged employees are individuals who are willing to go an extra mile and exert their efforts at work, with passion, loyalty and integrity for the wellbeing of the organisation. Hence organizations should thrive to enhance employee engagement through effective strategies such as improving working conditions, encouraging employee involvement and participation so as to achieve effective organisational commitment and enjoy its associated benefits.

The findings of this study also reflected that transformational leadership plays a significant role in boosting organisational commitment. Due to their leadership qualities and attributes, transformational leaders possess the ability to transform the behaviour of their followers by cultivating in it the desirable components of organisational commitment. Based on the findings of this research, transformational leadership is associated with a harmonious industrial relations system that is characterised by a health relationship between employees and employers, employees and their leaders, and employees and employees. As such, this study 
implies that a good fit between a leader and a follower is a key determinant of effective organisational commitment. Hence managers should always opt for leadership styles that are best suitable for winning the hearts of employees so as to encourage effective organisational commitment.

Leaders of organisations are also encouraged to establish communication channels that are fair, open and non-discriminatory in nature for the benefit of all the internal stakeholders of an organisation. According to the findings of this study, organisational communication has a positive effect on organisational commitment. Open and inclusive channels of organisational communication often boost employees' organisational commitment.

Given the benefits of organisational commitment that have been found in this research, such as improved employee performance, productivity, loyalty, responsibility, job satisfaction, motivation and a harmonious industrial relations system, it is recommended that organizations should come up with strategies that are aimed at stimulating effective organisational commitment among employees.

\section{References}

Bass, B. M., \& Avolio, B. J. (1993). Transformational leadership and organizational culture. Public administration quarterly, 112-121. https://www.jstor.org/stable/40862298

Bedarkar, M., \& Pandita, D. (2014). A study on the drivers of employee engagement impacting employee performance. Procedia-Social and Behavioral Sciences, 133, 106-115. https://doi.org/10.1016/j.sbspro.2014.04.174

Bhappu, A. D., \& Schultze, U. (2018). Implementing an Organization-sponsored Sharing Platform to Build Employee Engagement. https://escholarship.org/uc/item/1m46f $8 \mathrm{dr}$

Carriere, J., \& Bourque, C. (2009). The effects of organizational communication on job satisfaction and organizational commitment in a land ambulance service and the mediating role of communication satisfaction. Career Development International, 14(1), 29-49. https://doi.org/10.1108/13620430910933565

Chen, J. C., Silverthorne, C., \& Hung, J. Y. (2006). Organization communication, job stress, organizational commitment, and job performance of accounting professionals in Taiwan and America. Leadership \& organization Development journal, 27(4), 242-249. https://doi.org/10.1108/01437730610666000

Conger, J. A., Kanungo, R. N., Menon, S. T., \& Mathur, P. (1997). Measuring charisma: dimensionality and validity of the Conger-Kanungo scale of charismatic leadership. Canadian Journal of Administrative Sciences/Revue Canadienne des Sciences de l'Administration, 14(3), 290-301. https://doi.org/10.1111/j.1936-4490.1997.tb00136.x

Cronk, B. C. (2019). How to use SPSS®: A step-by-step guide to analysis and interpretation. Routledge. https://trove.nla.gov.au/work/26870530

Dey, T., Kumar, A., \& Kumar, Y. L. N. (2014). A new look at the antecedents and consequences of organizational commitment: a conceptual study. Published in International Journal of Humanities and Social Sciences.Available at: https://ssrn.com/abstract=2695672

Ghorbanhosseini, M. (2012). Analysis of team working on organisational commitment in Safa Industrial Group in Iran. International Journal of Engineering and Science, 1(3)22-25. In Hanaysha, J. (2016). Examining the Effects of Employee Empowerment, Teamwork, and Employee Training on Organisational Commitment. Procedia - Social and Behavioral Sciences. 229 (2016) 298-306. https://doi.org/10.1016/j.sbspro.2016.07.140

Glavas, A. (2016). Corporate social responsibility and employee engagement: Enabling employees to employ more of their whole selves at work. Frontiers in psychology, 7, 796. https://doi.org/10.3389/fpsyg.2016.00796

Gözükara, İ., \& Şimşek, O. F. (2015). Linking transformational leadership to work engagement and the mediator effect of job autonomy: a study in a Turkish private non-profit university. Procedia-Social and Behavioral Sciences, 195, 963971. Available at: https://doi.org/10.1016/j.sbspro.2015.06.274

Guney, S., Diker, O., Guney, S., Ayranci, E., and Solmaz, H. (2012). Effects of Organisational Communication on Work Commitment: A case study on a Public Agency in Ankara. Business Management Dynamics, 2 (4) 18-29. Available at: https://www.bmdynamics.com Available at: https://www.bmdynamics.com

Hanaysha, J. (2016). Testing the effects of employee engagement, work environment, and organizational learning on organizational commitment. Procedia-Social and Behavioral Sciences, 229, 289-297. https://doi.org/10.1016/j.sbspro.2016.07.139 
Hanaysha, J. (2016). Examining the effects of employee empowerment, teamwork, and employee training on organizational commitment. Procedia-Social and Behavioral Sciences, 229, 298-306. https://doi.org/10.1016/j.sbspro.2016.07.140

Hayase, L. K. T. (2009). Internal communication in organizations and employee engagement. http://digitalscholarship.unlv.edu/cgi/viewcontent.cgi?article=2177\&context=thesesdissertations

Genevičiūtė-Janoniené, G., \& Endriulaitienè, A. (2014). Employees' organizational commitment: Its negative aspects for organizations. Procedia-Social and Behavioral Sciences, 140, 558-564. https://doi.org/10.1016/j.sbspro.2014.04.470

Jaros, S. J. (1997). An assessment of Meyer and Allen's (1991) three-component model of organizational commitment and turnover intentions. Journal of vocational behavior, 51(3), 319-337. https://doi.org/10.1006/jvbe.1995.1553

Kaliannan, M., \& Adjovu, S. N. (2015). Effective employee engagement and organizational success: a case study. Procedia-Social and Behavioral Sciences, 172, 161-168. https://doi.org/10.1016/j.sbspro.2015.01.350

Kwon, I. W. G., \& Banks, D. W. (2004). Factors related to the organizational and professional commitment of internal auditors. Managerial Auditing Journal, 19(5), 606-622. https://doi.org/10.1108/02686900410537748

Lo, M. C., Ramayah, T., Min, H. W., \& Songan, P. (2010). The relationship between leadership styles and organizational commitment in Malaysia: role of leader-member exchange. Asia Pacific business review, 16(1-2), 79103. https://doi.org/10.1080/13602380903355676

Meyer, J. P., \& Allen, N. J. (1991). A three-component conceptualization of organizational commitment. Human resource management review, 1(1), 61-89. https://doi.org/10.1016/1053-4822(91)90011-Z

Mowday, R. T., Steers, R. M., \& Porter, L. W. (1979). The measurement of organizational commitment. Journal of vocational behavior, 14(2), 224-247. https://doi.org/10.1016/0001-8791(79)90072-1

Nunnally, J. C. (1994). Psychometric theory 3E. Tata McGraw-Hill Education. https://books.google.com.pk/books?hl=en\&lr=\&id=_6R_f3G58JsC\&oi=fnd\&pg=PR21\&dq=Nunnally,+J.+C.+(1978).+ Psychometric+Theory.+New+York:+McGraw-

Hill.\&ots=MXQLDwSANk\&sig=BswnUJaoWoPAh8FeXoOSr3q4X28\&redir_esc $=\mathrm{y} \# \mathrm{v}=$ onepage\&q\&f=false

Schaufeli, W. B., and Bakker, A. B. (2003). Utrecht work engagement scale: Preliminary manual. Organisational Health Psychology Unit, Utrecht University, Utrecht. In Hanaysha, J. (2016). Testing the Effects of Employee Engagement, Work Environment and Organizational Learning on Organisational Commitment. Procedia - Social and Behavioural Sciences, 299 (2016) 289 - 297. Available at: https://doi.org/10.1016/j.sbspro.2016.07.139

Rasli, A., Tat, H. H., Chin, T. A., \& Khalaf, B. (2012). Employee engagement and employee shareholding program in a multinational company in Malaysia. Procedia-Social and behavioral sciences, 40, $209-214$. https://doi.org/10.1016/j.sbspro.2012.03.182

Shoko, M., \& Zinyemba, A. Z. (2014). Impact of employee engagement on organizational commitment in national institutions of higher learning in Zimbabwe. International Journal of Advanced Research in Management and Social Sciences, 3(9), 255-268. http://garph.co.uk/ijarmss/sep2014/21.pdf

Cheah, C. S., Chong, V. S. W., Yeo, S. F., \& Pee, K. W. (2016). An empirical study on factors affecting organizational commitment among generation X. Procedia-Social and Behavioral Sciences, 219, 167-174. https://doi.org/10.1016/j.sbspro.2016.05.002 